\title{
Perbedaan Penguasaan Konsep Kerja Larutan Penyangga Hasil Pembelajaran Menggunakan LKS-Induktif Dan LKS-Deduktif Pada Siswa Kelas XI MIPA SMA Negeri 2 Palangka Raya Tahun Ajaran 2018/2019
}

\author{
Indra Gunawan Barutu*, Abudarin, Nopriawan Berkat Asi \\ Program Studi Pendidikan Kimia, Universitas Palangka Raya, Indonesia \\ *E-mail: barutuindra@gmail.com
}

\begin{abstract}
Abstrak
Mengacu pada kurikulum 2013, pembelajaran menggunakan LKS adalah salah satu cara guru untuk berperan sebagai fasilitator dalam pembelajaran kimia. Larutan penyangga merupakan pengetahuan konseptual, sehingga LKS dapat dirancang dengan alur berpikir induktif dan deduktif. Penelitian ini bertujuan untuk mengetahui perbedaan penguasaan siswa pada konsep kerja larutan penyangga hasil pembelajaran menggunakan LKS-induktif dan deduktif.

Penelitian ini merupakan penelitian eksperimental dengan desain 'PretesPostes Control Group'. Dua kelompok kelas dipilih sebagai sampel yang diambil dengan teknik Cluster Random Sampling. Satu kelas disebut sebagai kelas induktif yaitu kelas yang diberi perlakuan belajar menggunakan LKS-induktif dan satu kelas disebut sebagai kelas deduktif yaitu kelas yang diberi perlakuan belajar menggunakan LKS-deduktif. Data penguasaan siswa dijaring menggunakan soal tes dalam bentuk soal uraian terbatas. Uji hipotesis dilakukan menggunakan uji statistik nonparametrik yaitu uji Mann Whitney U Test.

Hasil uji Mann Whitney U Test pada taraf signifikasi 5\% menggunakan program SPSS versi 25 adalah $0.856(0.856>0.05)$, sehingga dapat disimpulkan bahwa tidak ada perbedaan penguasaan konsep kerja larutan penyangga hasil pembelajaran menggunakan LKS-induktif dan deduktif pada siswa kelas XI MIPA SMA Negeri 2 Palangka Raya tahun ajaran 2018/2019.
\end{abstract}

Kata Kunci: Larutan Penyangga, Deduktif, Induktif, Penguasaan Konsep 


\section{Pendahuluan}

Kimia adalah kajian mengenai materi, energi, dan interaksi di antara keduanya. Kimia menekankan pada kajian materi, termasuk komponen, sifat, struktur, perubahan yang dialaminya, dan hukum yang mengendalikan perubahan tersebut (Chang, 2005; Goldberg, 2008; dan Ghalib, 2009).

Kimia dikenal sebagai mata pelajaran yang sukar dipahami oleh siswa SMA/MA sederajat karena memiliki perbendaharaan kata yang sangat khusus. Awalnya, mempelajari kimia sama seperti mempelajari bahasa yang baru, selain itu beberapa konsepnya bersifat abstrak (Chang, 2005).

Larutan penyangga adalah salah satu pokok materi yang dibahas pada mata pelajaran kimia tingkat SMA/MA sederajat. Konsep-konsep pada materi larutan penyangga mutlak harus dipahami siswa secara menyeluruh karena akan terus diimplementasikan pada konsep-konsep kimia berikutnya maupun dalam kehidupan sehari-hari (Suyanti, 2010).

Cara kerja larutan penyangga merupakan konsep yang jarang diajarkan guru kepada siswa karena bersifat abstrak. Hal ini dibuktikan dari hasil penelitianpenelitian yang telah dilakukan oleh mahasiswa Program Studi Pendidikan Kimia UPR yang berhasil diinventaris oleh penulis. Penulis menemukan fakta bahwa konsep-konsep tentang larutan penyangga yang termuat pada indikator penelitianpenelitian tersebut meliputi: Konsep sifat, komponen, dan cara menghitung larutan penyangga. Indikator pada penelitian-penelitian tersebut belum sesuai dengan kompetensi dasar (KD) pada kurikulum 2013, yaitu pada KD. 3.12. yang berbunyi menjelaskan prinsip kerja, perhitungan $\mathrm{pH}$ dan peran larutan penyangga dalam tubuh makhluk hidup (kurikulum, 2013). Fakta bahwa belum ada penelitian yang mengkaji penguasaan konsep siswa terhadap kerja larutan penyangga, 
menunjukkan bahwa penting untuk dilakukan penelitian yang mengkaji penguasaan konsep siswa pada pada konsep cara kerja larutan penyangga.

Karakteristik konsep-konsep pada materi larutan penyangga adalah pengetahuan yang berjenis konseptual. Syarat dari jenis pengetahuan konseptual adalah belajar dari fakta dan ide-ide yang menyatakan hubungan antara keduanya. Ranah pengetahuan konseptual berorientasi pada pengetahuan tentang prinsip, generalisasi dan juga pengetahuan tentang teori. Dengan karakteristik konsep seperti ini, materi larutan penyangga dapat dipelajari dengan alur berpikir induktif atau deduktif. Alur berpikir induktif adalah suatu proses berpikir yang berlangsung dari khusus menuju umum. Orang mencari ciri-ciri atau sifat-sifat tertentu dari berbagai fenomena, kemudian menarik kesimpulan bahwa ciri-ciri atau sifat-sifat itu terdapat pada semua jenis fenomena. Alur berpikir deduktif adalah proses penalaran yang bermula dari keadaan umum ke keadaan khusus sebagai pendekatan yang bermula dengan menyajikan aturan, prinsip umum itu ke dalam keadaan khusus (Sagala, 2014).

Mengacu pada kurikulum 2013 yang berbasis karakter dan kompetensi, siswa diwajibkan untuk aktif dalam proses pembelajaran. Hal demikian merubah peran guru yang sebelumnya aktif bertindak sebagai pemberi pengetahuan kepada peserta didik menjadi fasilitator untuk memampukan peserta didik aktif membangun sendiri pengetahuannya (Kurikulum 2013). Hal ini tentu merubah budaya pembelajaran yang biasa dilakukan dengan ceramah (belajar dengan alur berpikir deduktif) menjadi pembelajaran berbasis penemuan (pembelajaran dengan alur berpikir induktif). 
Salah satu cara yang dapat dilakukan oleh guru sebagai fasilitator saat proses pembelajaran adalah dengan menggunakan media pembelajaran. Media yang dapat digunakan oleh guru dalam proses pembelajaran adalah lembar kerja (LK). Penggunaan LK lebih praktis dan mempunyai hasil yang bagus dalam penerapannya (Kurniawan, dkk, 2012) dibandingkan media seperti video atau laboratorium karena lembar kerja dapat dirancang sesuai dengan materi atau konsep yang akan dipelajari siswa. Hal tersebut juga didukung dari hasil penelitan Agustina (2013) dan Novianti (2017). Hasil penelitian Agustina (2013) pada skripsinya yang berjudul “Analisis Pemahaman Konsep Larutan Penyangga Basa Hasil Pembelajaran dengan Menggunakan Lembar Kerja Indukif Pada Siswa Kelas XI IPA 1 SMAN-4 Palangka Raya“, menyatakan bahwa pembelajaran menggunakan LKS berhasil untuk meningkatkan pemahaman siswa dalam mempelajari konsep larutan penyangga.

Hasil penelitian Novianti (2017) tentang "Pengaruh Penggunaan Lembar Kerja Mahasiswa (LKM) terhadap Penguasaan Konsep Larutan Penyangga dalam Mempertahankan pH Sistem Kesetimbangan Asam Basa pada Mahasiswa Semester II Program Studi Pendidikan Kimia Universitas Palangka Raya Tahun Akademik 2016/2017”, juga menyatakan bahwa pembelajaran menggunakan alur berpikir deduktif mampu meningkatkan penguasaan konsep mahasiswa pada materi larutan penyangga.

Hasil penelitian Agustina (2013) dan Novianti (2017) menunjukkan bahwa penggunaan LKS-induktif dan deduktif mampu meningkatkan penguasaan konsep pengguna LKS-induktif dan deduktif pada materi larutan penyangga. Hal ini menunjukkan bahwa pembelajaran dengan alur berpikir induktif maupun deduktif 
dapat digunakan sebagai pendekatan pembelajaran pada materi larutan penyangga. Meskipun pembelajaran menggunakan alur berpikir induktif dan deduktif mampu meningkatkan penguasaan konsep peserta didik pada materi larutan penyangga, namun keberhasilan peserta didik menggunakan alur berpikir induktif dan deduktif tergantung dari kebiasaan/pengalaman peserta didik belajar menggunakan alur berpikir induktif maupun deduktif dan kompleksitas dari konsep yang dipelajari, sehingga belajar menggunakan LKS dengan alur berpikir yang berbeda (alur berpikir induktif dan deduktif) diduga memberikan perbedaan terhadap penguasaan konsep siswa pada konsep kerja larutan penyangga. Berdasarkan uraian-uraian yang telah dijelaskan, penting untuk dilakukan penelitian dengan judul "perbedaan penguasaan konsep kerja larutan penyangga hasil pembelajaran menggunakan LKS-induktif dan LKS-deduktif pada siswa kelas XI MIPA SMA Negeri 2 Palangka Raya tahun ajaran 2018/2019”.

Adapun rumusan masalah dalam penelitian ini adalah apakah hasil pembelajaran menggunakan LKS-induktif berbeda dengan LKS-deduktif terhadap penguasaan konsep kerja larutan penyangga yang dibuat secara langsung pada siswa kelas XI MIPA SMA Negeri 2 Palangka Raya tahun ajaran 2018/2019?

Penelitian ini bertujuan untuk mendeskripsikan perbedaan penguasaan konsep kerja larutan penyangga yang dibuat secara langsung hasil pembelajaran menggunakan LKS-induktif dan LKS-deduktif pada siswa kelas XI MIPA SMA Negeri 2 Palangka Raya tahun ajaran 2018/2019. 


\section{Metodologi Penelitian}

Metode pada penelitian ini adalah metode eksperimental. Eksperimen dilakukan dengan merancang dua LKS dengan alur berpikir yang berbeda, yaitu dengan alur berpikir induktif dan deduktif. LKS yang dirancang berbeda digunakan untuk mengetahui apakah terdapat perbedaan penguasaan konsep terhadap dua sampel kelas yang diberikan perlakuan pembelajaran menggunakan LKS dengan alur berpikir yang berbeda.

Waktu pengumpulan data dilaksanakan pada bulan Maret-April 2019. Sampel pada penelitian ini adalah siswa kelas XI MIPA 1 dan 4 SMA Negeri 2 Palangka Raya tahun ajaran 2018/2019 yang diambil menggunakan teknik cluster random sampling.

Instrumen yang digunakan untuk memperoleh data dalam penelitian ini, yaitu:

1. Lembar kerja siswa (LKS). LKS adalah LKS adalah lembar panduan kegiatan belajar yang harus diisi siswa.

2. Tes penguasaan konsep (pretes dan postes). Instrumen pada penelitian ini berupa esai berjumlah 6 soal untuk mengetahui penguasaan konsep siswa terhadap materi kerja larutan penyangga. Pretes dan postes merupakan soal yang berbeda.

Data pada penelitian ini berupa skor penguasaan konsep siswa pada konsep kerja larutan penyangga. Langkah-langkah pengumpulan data dalam penelitian ini meliputi: 
1. Memberikan pretes kepada siswa kelas induktif dan deduktif. Pemberian pretes bertujuan untuk mengetahui penguasaan konsep awal siswa terhadap konsep kerja larutan penyangga. Pengerjaan pretes dilakukan selama 15 menit.

2. Memberikan LKS-induktif kepada kelas induktif dan LKS-deduktif kepada kelas deduktif. Proses pembelajaran menggunakan LKS dapat dilakukan dengan cara berdiskusi dengan teman sebangku. Pembelajaran menggunakan LKS dilaksanakan selama 50 menit.

3. Memberikan postes kepada siswa kelas induktif dan deduktif. Pemberian postes bertujuan untuk mengetahui penguasaan konsep siswa terhadap konsep kerja larutan penyangga setelah belajar menggunakan LKS-induktif dan deduktif. Pengerjaan postes dilakukan selama 15 menit.

Data pretes dan postes diolah dengan langkah-langkah sebagai berikut:

1. Lembar jawaban pretes dan postes yang telah dikerjakan siswa diperiksa sesuai kunci jawaban.

2. Data pretes dan postes diberikan skor sesuai rubrik penskoran. Total skor yang diperoleh siswa dikonversikan ke dalam bentuk persentase penguasaan konsep siswa dengan rumus berikut:

$$
\text { Nilai }=\frac{\text { jumlah skor yang diperoleh siswa }}{\text { jumlah skor maksimal }} \times 100 \%
$$

3. Skor pretes dan postes siswa di coding, kemudian ditabulasikan.

Data pretes dan postes dianalisis menggunakan program analisis, yaitu SPSS versi 25 pada taraf signifikasi $\alpha=0,05$ dengan tahapan sebagai berikut:

1. Uji Prasyarat Analisis. Uji prasyarat analisis yang dilakukan pada penelitian adalah uji normalitas. Uji normalitas digunakan untuk mengetahui tingkat 
kenormalan data nilai pretes dan postes siswa kelas induktif dan kelas deduktif.

2. Uji Prasyarat Hipotesis. Uji prasyarat pada penelitian ini menggunakan uji Wilcoxon Signed Rank Test yang dilakukan pada kelas induktif dan deduktif. Uji Wilcoxon Signed Rank Test bertujuan untuk mengetahui apakah terdapat perbedaan antara nilai pretes dan postes pada suatu kelas yang telah diberikan perlakuan menggunakan LKS pada saat proses pembelajaran. Data yang dianalisis pada uji Wilcoxon Signed Rank Test adalah data pretes dan postes dari kelas induktif dan deduktif.

3. Uji Hipotesis. Uji hipotesis pada penelitian ini menggunakan uji Mann Whitney U Test. Data yang dianalisis pada uji Mann Whitney U Test adalah data nilai postes kelas induktif dan deduktif. Uji Mann Whitney U Test digunakan untuk mengetahui apakah terdapat perbedaan penguasaan konsep kerja larutan penyangga hasil pembelajaran menggunakan LKS-induktif dan LKS-deduktif pada siswa kelas XI MIPA SMA Negeri 2 Palangka Raya tahun ajaran 2018/2019. Hipotesis pada penelitian ini disusun sebagai berikut.

$\mathrm{H}_{0}=\quad$ Tidak ada perbedaan penguasaan konsep kerja larutan penyangga hasil pembelajaran menggunakan LKS-induktif dan deduktif pada siswa kelas XI MIPA SMA Negeri 2 Palangka Raya tahun ajaran 2018/2019.

$\mathrm{Ha}=$ Ada perbedaan penguasaan konsep kerja larutan penyangga hasil pembelajaran menggunakan LKS-induktif dan deduktif pada siswa kelas XI MIPA SMA Negeri 2 Palangka Raya tahun ajaran 2018/2019. $\mathrm{H}_{0}: \mu_{1}=\mu_{2}$ $\mathrm{H}_{\mathrm{a}}: \mu_{1} \neq \mu_{2}$ 
Keterangan:

$\mu_{1}=$ Penguasaan konsep kerja larutan penyangga hasil pembelajaran menggunakan LKS-induktif pada siswa kelas XI MIPA SMA Negeri 2 Palangka Raya tahun ajaran 2018/2019.

$\mu_{2}=$ Penguasaan konsep kerja larutan penyangga hasil pembelajaran menggunakan LKS-deduktif pada siswa kelas XI MIPA SMA Negeri 2 Palangka Raya tahun ajaran 2018/2019.

Dasar pengambilan keputusan dalam Uji Mann Whitney U Test adalah sebagai berikut:

1. Jika nilai Asymp.Sig. lebih kecil dari <0.05, maka Ha diterima.

2. Jika nilai Asymp.Sig. lebih besar dari > 0.05, maka Ha ditolak.

\section{Hasil Penelitian Dan Pembahasan}

Hal yang paling penting dalam pelaksanaan pembelajaran adalah terlebih dahulu dilakukannya simulasi pembelajaran. Simulasi pembelajaran dilakukan di kelas XI MIPA 2 dan 3 SMA Negeri 2 Palangka Raya. Kelas XI MIPA 2 sebagai kelas yang mendapatkan perlakuan dengan LKS-induktif pada saat simulasi pembelajaran dan kelas XI MIPA 3 sebagai kelas yang mendapatkan perlakuan dengan LKS-deduktif pada saat simulasi pembelajaran. Simulasi berlangsung selama 1 kali pertemuan tiap kelas.

Pengambilan data dilakukan terhadap siswa kelas XI MIPA SMA Negeri 2 Palangka Raya pada semester genap tahun ajaran 2018/2019. Penelitian terbagi 
menjadi dua kelas, 31 orang siswa dari kelas XI MIPA 1 sebagai kelas yang mendapatkan perlakuan dengan LKS-deduktif pada saat pembelajaran dan 30 orang siswa kelas XI MIPA 4 sebagai kelas yang mendapatkan perlakuan dengan LKS-induktif pada saat proses pembelajaran.

Deskripsi data penguasaan konsep siswa terdiri dari pretes dan postes.

Hasil analisis dirangkum ke dalam Tabel 9.

Tabel 9. Statistik Deskripsi Hasil Belajar Siswa Kelas Induktif dan Deduktif

\begin{tabular}{lllllll}
\hline Kelompok & & $\mathrm{N}$ & Mean & SD & Min & Max \\
\hline Induktif & Pretes & 30 & 8.64 & 10.22 & 0 & 27 \\
& Postes & 30 & 62.42 & 23.60 & 18 & 100 \\
Deduktif & Pretes & 31 & 9.82 & 8.87 & 0 & 32 \\
& Postes & 31 & 64.37 & 22.88 & 18 & 100 \\
\hline
\end{tabular}

Data nilai tes digunakan untuk mengetahui hasil perlakuan yang diberikan, dengan dilakukannya beberapa uji meliputi uji prasyarat analisis, uji prasyarat hipotesis dan uji hipotesis. Hasil setiap uji tersebut dijelaskan sebagai berikut:

1. Uji Prasyarat Analisis. Hasil uji normalitas dirangkum ke dalam Tabel 1.

Tabel 1. Uji Normalitas Shapiro-Wilk

\begin{tabular}{lll}
\hline Hasil & Kelas & Signifikasi \\
Belajar & Pretes_Induktif & 0.000 \\
Siswa & Postes_Induktif & 0.154 \\
& Pretes_Deduktif & 0.003 \\
& Postes_Deduktif & 0.212 \\
\hline
\end{tabular}

\section{a. Liliefors Significance Correction}

Sumber: SPSS Versi 25.

Data pretes siswa kelas induktif dan deduktif pada Tabel 1 tidak berdistribusi normal, sehingga pada penelitian ini uji statistik dilakukan dengan uji non statistik non parametrik. Uji statistik non parametrik tidak mensyaratkan 
data harus berdistribusi normal dan homogen, sehingga uji normalitas dan uji homogenitas pada penelitian ini tidak dilakukan.

2. Hasil analisis uji Wilcoxon Signed Rank Test pada kelas induktif dan deduktif dijelaskan sebagai berikut.

a. Hasil Uji Prasyarat Hipotesis pada Kelas Induktif

Tabel 3. Tes Statistik Wilcoxon Signed Rank Test Kelas Induktif

\begin{tabular}{lc}
\hline Z & $-4.785^{\mathrm{b}}$ \\
Asymp. Sig (2-tailed) & 0.000 \\
\hline
\end{tabular}

a. Wilcoxon Signed Rank Test Signed Rank Test

b. Based on negative rank

b. Hasil Uji Prasyarat Hipotesis pada Kelas Deduktif

Tabel 4. Tes Statistik Wilcoxon Signed Rank Test Kelas Deduktif

\begin{tabular}{lc}
\hline $\mathrm{Z}$ & $-4.862^{\mathrm{b}}$ \\
Asymp. Sig (2-tailed) & .000 \\
\hline
\end{tabular}

a. Wilcoxon Signed Rank Test Signed Rank Test

b. Based on negative rank

Hasil analisis Wilcoxon Signed Rank Test pada Tabel. 3 dan 4 menunjukkan bahwa nilai pretes dan postes siswa kelas induktif dan deduktif adalah 0.000 ( $0.000<0,05)$. Hasil ini menunjukkan bahwa secara signifikan nilai pretes dan postes siswa kelas induktif hasil pembelajaran menggunakan LKS-induktif berbeda, sehingga analisis dapat dilanjutkan ke tahap uji hipotesis.

3. Uji Hipotesis. Uji Mann Whitney digunakan sebagai uji hipotesis pada penelitian ini. Hasil uji analisis Mann Whitney dirangkum ke dalam Tabel 14. Tabel 14. Hasil Uji Statistik Mann Whitney Kelas Indukif dan Kelas Deduktif 


\begin{tabular}{lc}
\hline Mean-Whitney U & 403.500 \\
Wilcoxon W & 868.500 \\
Z & -.889 \\
Asymp. Signifikasi & .374 \\
\hline
\end{tabular}

a. Gruping variable : Kelas

Tabel 14 menunjukkan bahwa nilai signifikasi hasil uji Mann Whitney adalah .374 (0.374 > 0.05), sehingga Ha ditolak dan Ho diterima, atau dapat disimpulkan bahwa tidak ada perbedaan penguasaan konsep kerja larutan penyangga hasil pembelajaran menggunakan LKS-induktif dan LKS-deduktif pada siswa kelas XI MIPA SMA Negeri 2 Palangka Raya pada tahun ajaran 2018/2019.

Hasil uji analisis Man Whiteney pada taraf signifikasi, $\alpha=0.05$ pada Tabel 14 menunjukkan bahwa tidak perbedaan penguasaan konsep siswa pada konsep kerja larutan penyangga hasil pembelajaran menggunakan LKS-induktif dan LKSdeduktif. Tidak ada perbedaan penguasaan siswa pada konsep kerja larutan penyangga hasil belajar menggunakan LKS-induktif dan deduktif terjadi karena LKS-induktif dan deduktif hanya dirancang berbeda pada alur berpikir, yaitu dari umum ke khusus atau khusus ke umum, tetapi konsep kerja larutan penyangga yang dimuat pada LKS-induktif dan deduktif tidak berbeda, sehingga penguasaan siswa kelas induktif dan deduktif pada konsep menjelaskan komponen penyusun larutan penyangga basa tidak berbeda.

\section{Simpulan}

Hasil dari analisis statistik uji Mann Whitney pada taraf signifikasi 5\% menggunakan program SPSS versi 25 adalah $0.856(0.856>0.05)$, atau dapat 
disimpulkan bahwa tidak ada perbedaan penguasaan konsep kerja larutan penyangga hasil pembelajaran menggunakan LKS-induktif dan LKS-deduktif pada siswa kelas XI IPA SMA Negeri 2 Palangka Raya tahun ajaran 2018/2019.

Hasil pembelajaran menggunakan LKS-Induktif dan deduktif terbukti dapat meningkatkan penguasaan konsep siswa pada konsep kerja larutan penyangga. Oleh karena itu, untuk melatih kemampuan berpikir siswa supaya dapat berpikir secara saintifik, pembelajaran dengan alur berpikir induktif dan deduktif dapat digunakan sebagai pendekatan dalam pembelajaran konsep kerja larutan penyangga dan konsep-konsep sejenis dalam mata pelajaran kimia.

\section{Daftar Referensi}

Achmad, H. 2001. Penuntun Belajar Kimia Dasar, Kimia Larutan Cetakan Kedua. Bandung: PT Citra Aditya Bakti.

Agustina, L. 2013. Analisis Penguasaan Konsep Larutan Penyangga Basa Hasil Pembelajaran Dengan Menggunakan Lembar Kerja Indukif Pada Siswa Kelas XI IPA 1 SMAN-4 Palangka Raya Tahun Ajaran 2012/2013. Skripsi Sarjana, tidak dipublikasikan, Universitas Palangka Raya.

Suharsimi, A. 2006. Prosedur Penelitian, Suatu Pendekatan Praktik. Jakarta: PT Rineka Cipta.

Chang, R. 2005. Kimia Dasar, Konsep-Konsep Inti Edisi Ketiga Jilid 1. Jakarta: Erlangga.

Djamarah, S. B., \& Aswan, Z. 2010. Pendekatan Belajar Mengajar. Jakarta: Rineka Cipta.

Gandjar, I. G. 2016. Kimia Medisinal Anorganik. Yogyakarta: Gadjah Mada University Press.

Ghalib, A. K. 2009. Buku Pintar Kimia. Jogjakarta: Power Books (Ihdina).

Goldberg, D. E. 2008. Kimia Untuk Pemula Edisi Ketiga. (Ed). Lemeda Simarmata. Jakarta: Erlangga.

Hamalik, O. 2014. Cetakan Kesembilan Psikologi Belajar Dan Mengajar. Bandung: Sinar Baru Algesindo.

Kurniawan, T. J. dan Joko, S.. 2012. Pengaruh Penggunaan Lembar Kerja Dengan Pendekatan Induktif Terhadap Kemampuan Berpikir Kritis Dan Kreatif Siswa Dalam Pembelajaran Fisika. Jurnal Penelitian Fisika, 3 (1): 20862407.

Kountur, R. 2007. Metode Penelitian untuk Penulisan Skripsi dan Tesis. Jakarta: PPM. 
Majid, A., \& Chaerul R. 2014. Pendekatan Ilmiah dalam Implementasi Kurikulum 2013 Cetakan ke-1. Bandung: PT Remaja Rosdakarya.

Neolaka, A. 2016. Metode Penelitian dan Statistik. Bandung: PT Remaja Rosdakarya.

Novianti, E. 2017. Pengaruh Penggunaan LKM Terhadap pH Penguasaan Konsep Larutan Penyangga Dalam Mempertahankan Sistem Kesetimbangan Asam Basa Pada Mahasiswa Semester II Program Studi Pendidikan Kimia Universitas Palangka Raya Tahun Akademik 2016/2017. Skripsi Sarjana, tidak dipublikasikan, Universitas Palangka Raya.

Rivai, H. 1995. Asas Pemeriksaan Kimia. Jakarta: Universitas Indonesia (UIPress).

Sagala, S. 2014. Konsep dan Makna Pembelajaran Untuk Membantu Memecahkan Problematika Belajar dan Mengajar Cetakan ke-12. Bandung: ALFABETA, CV.

Sudarmo, U. \& Mitayani, N. 2016. Kimia untuk SMA/MA Kelas XI Kurikulum 2013 yang Disempurnakan, Peminatan Matematika dan Ilmu Pengetahuan Alam. Surakarta: Erlangga.

Sunarya, Y. 2003. Kimia Dasar 2, Berdasarkan Prinsip-Prinsip Kimia Terkini. Bandung: Alkemi Grafisindo Press.

Suwangsih, E dan Tiurlina. 2006. Model Pembelajaran Matematika. Bandung: UPI Press.

Suyanti, R. D. 2010. Pendekatan Pembelajaran Kimia Edisi Pertama. Yogyakarta; Graha Ilmu.

Widyoko, E. P. 2012. Teknik Penyusunan Instrumen Penelitian Cetakan Pertama. Yogyakarta: Pustaka Pelajar. 